\title{
Effect of Bellamya purificata on organic matter degradation in surface sediment as revealed by amino acids
}

\author{
Yiran Hou ${ }^{1}$, Bing $\mathrm{Li}^{1}{ }^{1}$, Jiawei $\mathrm{Luo}^{2}$, Chengfeng Zhang ${ }^{1}$, Jie He ${ }^{1}$, Jian $\mathrm{Zhu}^{1, *}$ \\ ${ }^{1}$ Key Laboratory of Freshwater Fisheries and Germplasm Resources Utilization, Ministry of Agriculture and Rural Affairs, \\ Freshwater Fisheries Research Center, Chinese Academy of Fishery Sciences, Wuxi 214081, PR China
}

${ }^{2}$ Wuxi Fisheries College, Nanjing Agricultural University, Wuxi 214081, PR China

\begin{abstract}
The accumulation of organic matter $(\mathrm{OM})$ in the sediment of aquaculture ponds is a potential threat for aquaculture ecosystems and the surrounding environment. The snail Bellamya purificata is a potential bioremediation species which may solve this problem. To investigate the effects of $B$. purificata on OM degradation in surface sediment, an $84 \mathrm{~d}$ experiment was carried out. The experimental setup entailed 6 glass tanks which were divided into B. purificata treatment (BPT) and control (CON). At the end of the experiment, a significantly lower degradation index (DI), reactivity index (RI), and carbon-normalized yield of amino acids were observed in BPT compared to CON, with mean \pm SD values of $-0.47 \pm 0.43,1.24 \pm 0.01$, and $6.24 \pm 0.44$, respectively. BPT showed higher oxidation-reduction potential and bacterial 16S rRNA gene copies than CON. Total organic carbon, total nitrogen, and total hydrolysable amino acid concentrations in the BPT treatment were $1.83 \pm 0.10 \%, 0.07 \pm 0.01 \%$, and $22.38 \pm 0.53 \mu \mathrm{mol} \mathrm{g}^{-1}$, respectively, all of which were significantly lower than in CON. A clustered heat-map of different indexes related to OM degradation in sediments showed the final BPT as one separate category, which was different from the initial samples and the final CON. Overall, B. purificata could effectively facilitate OM degradation by promoting oxidation-reduction potential and bacterial populations, and ultimately by inhibiting the OM accumulation in sediment. Our results therefore provide support for the application of $B$. purificata to reduce the risk of endogenous pollution caused by OM accumulation in aquaculture ponds.
\end{abstract}

KEY WORDS: Bellamya purificata $\cdot$ Bioturbation · Aquaculture ecosystem - Organic matter degradation $\cdot$ Sediment $\cdot$ Amino acid

\section{INTRODUCTION}

The most important component of China's freshwater aquaculture industry is pond aquaculture, the total production and area of which account for 73.05 and $47.12 \%$ of freshwater aquaculture, respectively (Ministry of Agriculture and Rural Affairs 2018). Traditional pond aquaculture is labour and resource intensive, with low resource utilization, and an increase in production and economic benefits can only be achieved by increasing stocking density and

${ }^{*}$ Corresponding author: zhuj@ffrc.cn feeding ad libitum (Liu 2011, Shao et al. 2011). A low utilization rate of feed results in large amounts of residual organic materials in the aquaculture ponds, consisting mainly of uneaten food, faeces, and organic detritus. A portion of the residual organic materials is discharged with wastewater and causes nutrient pollution in the surrounding environment (Ji et al. 2000), while most of the residual organic materials accumulate on the sediment by settlement, complexation, and adsorption (Liu 2011, Shao et al. 2011).

(1) The authors 2021. Open Access under Creative Commons by Attribution Licence. Use, distribution and reproduction are unrestricted. Authors and original publication must be credited. 
In the aquaculture ecosystem, sediment, as a carrier for the migration, transformation, and accumulation of biogenic elements, is central as a sink for organic material and nutrient cycling. The accumulation of organic matter (OM) in sediments is a potential threat for aquaculture ecosystems and the surrounding environment (Diaz 2001, Sanz-Lázaro \& Marín 2008). In aquaculture ponds, the sediment, which is an important source of biogenic elements, can release nutrients and toxic substances into the upper water body, thereby causing endogenous pollution and eutrophication of the aquaculture ecosystem (Christensen et al. 2000, Gray et al. 2002, Hargrave et al. 2008, Carlsson et al. 2012).

Benthic fauna, which are important components of the benthic environment in aquatic ecosystems, can change the physical structure and chemical properties of sediments, accelerate material exchange between the sediment-water interface, affect the biogeochemical processes at the sediment-water interface, and alter the structure and evolution of benthic communities through motion, ingestion, breathing, excretion, and burrowing (Aller 1988, Pelegrí \& Blackburn 1994, Murray et al. 2002, Papaspyrou et al. 2006, Stockdale et al. 2009, Zhang et al. 2010). The snail Bellamya purificata is an important freshwater benthic organism, with wide distribution in China and high production (Liu 1979, Cao \& Jiang 1998, Yan et al. 2018). Due to its nutritional value, B. purificata is not only one of the most important baits for various commercial aquatic animals (Dong et al. 2009, Tian et al. 2012), but is also an important aquatic product favoured by people that has increasingly gained attention (Liang et al. 2013, Yan et al. 2018). B. purificata is one of the most important benthic organisms in rivers and lakes in China, and prefers to inhabit silt and ingest organic debris and algae in its surroundings (Reavell 1980, Cao \& Jiang 1998). Previous studies have shown that $B$. purificata can effectively improve the water quality in surrounding aquaculture (Chen et al. 2012, Zhao 2014), and it can provide important ecosystem services (Brönmark \& Vermaat 1998, Gu et al. 2015). Hence, B. purificata is not only an important economical aquaculture species but also a potentially valuable species for ecological aquaculture.

Amino acids (AAs) are among the most labile fractions of bulk OM and can provide insight into the diagenetic alteration of OM (Cowie \& Hedges 1992, Dauwe \& Middelburg 1998, Dauwe et al. 1999, Kaiser $\&$ Benner 2008). AAs are very useful indicators for evaluating the degradation state of particulate OM, dissolved OM, and sedimentary OM and have been widely applied in both marine and freshwater envi- ronments (Amon et al. 2001, Davis et al. 2009, Kaiser \& Benner 2009, Bourgoin \& Tremblay 2010, Fernandes et al. 2014, Chen et al. 2016, Wang et al. 2018). However, to date, no quantitative studies have applied AAs as biomarkers to study OM degradation and recycling in an aquaculture pond ecosystem.

In this study, we used AAs to determine the degradation state of $\mathrm{OM}$ in sediment and to quantify the influence of $B$. purificata on OM degradation. We also aimed to provide evidence supporting the application of $B$. purificata to inhibit the accumulation of $\mathrm{OM}$ in pond sediment, thereby promoting the sustainable development of aquaculture.

\section{MATERIALS AND METHODS}

\subsection{Culture experiment}

The experiment was conducted at the laboratory of the Freshwater Fisheries Research Center, Chinese Academy of Fishery Sciences. Bellamya purificata were collected from a local aquatic products trading market. The sediments were obtained from an aquaculture pond in the Dapu aquaculture base (Wuxi, Jiangsu, China). To maintain the consistency and homogeneity of the sediments in each glass tank, all sediments were dried in the sun, ground to a powder in a mortar to pass through a $100 \mu \mathrm{m}$ mesh sieve, and mixed evenly before use (Nie et al. 2011, Wang et al. 2015, Hou et al. 2018). A $5 \mathrm{~cm}$ thick layer of sediment was spread on the bottom of each experimental glass tank $(63 \times 43 \times 37 \mathrm{~cm})$, and all tanks were filled with filtered tap water. The sediment in each tank was then decanted and stabilized for $1 \mathrm{wk}$ prior to the experiment. Prior to the experiment, B. purificata were cultured in glass tanks with $5 \mathrm{~cm}$ of sediment for $14 \mathrm{~d}$ to acclimatize to the laboratory conditions. $B$. purificata treatment (BPT) and control (CON) tanks were set up in the experiment with 3 replicates each. After acclimation, 75 snails with initial weights of (mean $\pm \mathrm{SD}$ ) $3.01 \pm 0.17 \mathrm{~g}$ were selected and randomly and equally distributed in the 3 glass tanks designated for BPT (25 ind. $\operatorname{tank}^{-1}$ ). The stocking density was approximately $277.78 \mathrm{~g} \mathrm{~m}^{-2}$, which was based on the density of $B$. purificata in ecological ditches used for water purification, as reported by Duan (2013). The CON tanks contained no snails, but all other experimental conditions were strictly consistent with the BPT tank conditions. The experimental diets were commercial compound feed (Tongwei Group), which was ground and sieved through a $100 \mu \mathrm{m}$ mesh. The total hydrolysable AA composition of the 
experimental diets is shown in Table 1. At 16:00 h every day, 6 portions of $1.5 \mathrm{~g}$ of feed (equal to $2 \%$ of the combined body weight of 25 snails) were weighed, and each portion was well mixed with fresh water and evenly poured into the tanks. The water temperature was maintained at $25.0 \pm 0.5^{\circ} \mathrm{C}$ according to Cao \& Jiang (1998). The experiment was conducted under natural sunlight. No water was exchanged during the experimental period. The experiment was conducted for $84 \mathrm{~d}$ (12 wk).

\subsection{Sample collection}

Prior to the experiment, 3 sediment samples were randomly collected as the initial samples after being dried, ground, screened, and well mixed. Sampling contributes substantially to the disturbance of the sediments; therefore, the remaining samples were collected at the end of the experiment. At the end of the experiment, 9 sampling points were randomly selected in each of the 6 tanks, and $0 \sim 1 \mathrm{~cm}$ surface sediment samples were collected with a plastic pipe measuring $2 \mathrm{~cm}$ in diameter. The sediment samples collected from the same glass tank were well mixed and then divided into 2 parts. One part of the sediment samples was stored in a freezer at $-20^{\circ} \mathrm{C}$ for the quantification of bacteria by absolute fluorescence quantitative PCR. The other part was dried in a lyophilizer (CHRIST LYO Alpha 1-4 LD plus), ground to a powder in a mortar to pass through a $100 \mu \mathrm{m}$ mesh sieve, and stored in a freezer at $-80^{\circ} \mathrm{C}$ until further analysis of the hydrolysable AA compositions, total organic carbon (TOC), and total nitrogen (TN). Oxidation-reduction potential (ORP) was measured at $1 \mathrm{~cm}$

Table 1. Total hydrolysable amino acid (THAA) composition of the experimental diet. Data are presented as mean \pm SD $(n=3)$. Asp: aspartic acid; Glu: glutamic acid; Ser: serine; His: histidine; Gly: glycine; Thr: threonine; Arg: arginine; Ala: alanine; Tyr: tyrosine; Cys: cysteine; Val: valine; Met: methionine; Phe: phenylalanine; Ileu: isoleucine; Leu: leucine; Lys: lysine; Pro: proline; $\beta$-Ala: $\beta$-alanine; $\gamma$-Aba: $\gamma$-amino butyric acid; ND: not determined

\begin{tabular}{|lc|cc|}
\hline Amino acid & Concentration & Amino acid & Concentration \\
\hline THAA $\left.(\mu \mathrm{mol} \mathrm{g})^{-1}\right)$ & $2009.29 \pm 61.52$ & Cys $(\mathrm{mol} \%)$ & $0.06 \pm 0.05$ \\
Asp $(\mathrm{mol} \%)$ & $9.67 \pm 0.00$ & Val $(\mathrm{mol} \%)$ & $5.84 \pm 0.05$ \\
Glu $(\mathrm{mol} \%)$ & $20.26 \pm 0.04$ & Met $(\mathrm{mol} \%)$ & $1.03 \pm 0.01$ \\
Ser $(\mathrm{mol} \%)$ & $6.14 \pm 0.11$ & Phe $(\mathrm{mol} \%)$ & $4.06 \pm 0.02$ \\
His $(\mathrm{mol} \%)$ & $2.14 \pm 0.16$ & Ileu $(\mathrm{mol} \%)$ & $3.99 \pm 0.01$ \\
Gly $(\mathrm{mol} \%)$ & $8.95 \pm 0.22$ & Leu $(\mathrm{mol} \%)$ & $7.48 \pm 0.13$ \\
Thr $(\mathrm{mol} \%)$ & $4.69 \pm 0.17$ & Lys $(\mathrm{mol} \%)$ & $3.85 \pm 0.01$ \\
Arg $(\mathrm{mol} \%)$ & $6.06 \pm 0.02$ & Pro $(\mathrm{mol} \%)$ & $6.74 \pm 0.43$ \\
Ala $(\mathrm{mol} \%)$ & $7.18 \pm 0.03$ & $\beta$-Ala $(\mathrm{mol} \%)$ & ND \\
Tyr $(\mathrm{mol} \%)$ & $1.82 \pm 0.02$ & $\gamma$-Aba $(\mathrm{mol} \%)$ & ND \\
\hline
\end{tabular}

depth intervals at the beginning of the experiment, and then after 2, 4, 8, and 12 wk using a Pt electrode coupled with an $\mathrm{Ag} / \mathrm{AgCl}$ reference electrode.

\subsection{Laboratory analyses}

\subsubsection{TOC and TN}

To determine the TOC and TN concentrations, the homogenized and freeze-dried sediment samples were acidified with $1: 1 \mathrm{HCl}$ at room temperature for $24 \mathrm{~h}$ to remove inorganic carbon. The acidified sediment samples were then oven-dried to a constant weight at $50^{\circ} \mathrm{C}$ for $48 \mathrm{~h}$. TOC and TN analyses were performed using a FlashEA 1112 Series NC Analyzer. The elemental analyses were calibrated by repeated inclusion of intra-laboratory acetanilide standard; the standard deviation of the repeated analyses was approximately $0.3 \%$.

\subsubsection{Degradation indicators}

To quantify the sedimentary AAs, the homogenized and freeze-dried sediment sample (150 mg dry weight) was weighed, placed into ampoules, and hydrolysed with $8 \mathrm{ml}$ of $6 \mathrm{~mol}^{-1} \mathrm{HCl}$ at $110^{\circ} \mathrm{C}$ for $24 \mathrm{~h}$ under $\mathrm{N}_{2}$ atmosphere. After hydrolysis, the hydrolysate was transferred to a $50 \mathrm{ml}$ centrifuge tube and diluted with Milli- ${ }^{\circledR}$ water to a volume of $50 \mathrm{ml}$. Subsequently, the hydrolysis mixture was centrifuged at $10000 \times \mathrm{g}$ for $10 \mathrm{~min}$ to remove all particles, and the hydrolysate was dried repeatedly under $\mathrm{N}_{2}$ atmosphere to remove the $\mathrm{HCl}$ (Chen et al. 2018). The dried hydrolysate was then redissolved in Milli- ${ }^{\circledR}$ water, and the hydrolysable AA components were derived according to the pre-column OPA/FMOC-C1 derivatization method (Godel et al. 1992). The derivatives were identified by HPLC (Agilent 1100), based on retention times and determined through comparison with external AA standard solutions containing 19 individual AAs.

The external AA standard solution (Sigma-Aldrich ${ }^{\circledR}$ ) contained 17 individual protein AAs: alanine (Ala), arginine (Arg), aspartic acid (Asp), cysteine (Cys), glutamic acid (Glu), glycine (Gly), histidine (His), isoleucine (Ileu), leucine (Leu), lysine (Lys), methionine 
(Met), phenylalanine (Phe), proline (Pro), serine (Ser), threonine (Thr), tyrosine (Tyr), and valine (Val). Two non-protein AA standards, $\beta$-alanine $(\beta$ Ala) and $\gamma$-amino butyric acid ( $\gamma$-Aba), were added.

The degradation state of the sediment was evaluated using the following indicators. Carbon-normalized yield of the total hydrolysable AAs (THAA-C\%; Davis et al. 2009) and nitrogen-normalized yield of the THAAs (THAA-N\%; Davis et al. 2009): carbon and nitrogen in THAAs, expressed as the proportion of TOC and TN, respectively, were calculated based on individual AA mass weights. THAA-C\% and THAA-N\% are widely used in the quantitative description of the degradation of OM, as they are good indicators of OM 'freshness' and degradation state (Cowie \& Hedges 1994, Keil et al. 2000, Amon et al. 2001, Amon \& Benner 2003). As OM continues to degrade, THAA-C $\%$ and THAA-N\% will continuously decline, indicating the preferential degradation of AAs relative to bulk TOC and TN, due to the labile character of THAAs (Cowie \& Hedges 1994, Chen et al. 2018, Zhou et al. 2018).

The degradation index (DI; Dauwe \& Middelburg 1998, Dauwe et al. 1999) was calculated based on the changes in the relative molar percentages ( $\mathrm{mol} \%$ ) of individual AAs in diagenesis. The DI considers changes in the entire suite of proteinaceous AAs for calculation to determine the relative degradation state of OM (Dauwe \& Middelburg 1998, Dauwe et al. 1999). Higher values of DI indicate a lower degree of degradation. The DI was calculated as:

$$
\mathrm{DI}=\sum_{i}\left[\frac{\operatorname{var}_{i}-\mathrm{AVGVar}_{i}}{\mathrm{STDVar}_{i}}\right] \times \text { fac.coef }_{i}
$$

where $\operatorname{var}_{i}$ is the original mol\% of $\mathrm{AA}_{i}, \mathrm{AVG} \operatorname{var}_{i}$ is the mean of $\mathrm{AA}_{i}$ in our data set, and STD $\operatorname{var}_{i}$ is the standard deviation of $\mathrm{AA}_{i}$ in our data set. The fac.coef. ${ }_{i}$ is the factor score coefficient for $\mathrm{AA}_{i}$ originating from Dauwe \& Middelburg (1998, their Table 4A).

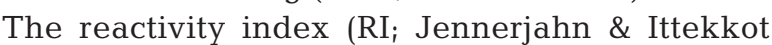
1997) describes OM reactivity and is calculated based on the relationship between aromatic and non-protein AAs, and their contributions in different degradation states. Generally, an RI value close to 0 implies the extensive degradation of OM, while fresh phytoplankton-derived OM has an RI value between 4 and 6 (Jennerjahn \& Ittekkot 1997). The RI was calculated as:

$$
\mathrm{RI}=\frac{\text { Tyr }+ \text { Phe }}{\beta-\text { Ala }+\gamma-\mathrm{Aba}}
$$

where Tyr, Phe, $\beta$-Ala, and $\gamma$-Aba are expressed as the relative molar percentages (mol\%).

\subsubsection{Absolute fluorescence quantitative PCR}

Genomic DNA was extracted from $0.5 \mathrm{~g}$ frozen sediment samples using the EZNA ${ }^{\circledR}$ Soil DNA Kit (Omega Bio-tek) according to the manufacturer's protocols. The bacteria 16S ribosomal RNA (16S rRNA) genes were amplified by PCR $\left(95^{\circ} \mathrm{C}\right.$ for $3 \mathrm{~min}$, followed by 35 cycles at $95^{\circ} \mathrm{C}$ for $30 \mathrm{~s}, 65^{\circ} \mathrm{C}$ for $30 \mathrm{~s}$, and $72^{\circ} \mathrm{C}$ for $30 \mathrm{~s}$ ) using primers $341 \mathrm{~F} 5^{\prime}-\mathrm{CCT}$ AYG GGR BGC ASC AG-3' and 806R 5'-GGA CTA CNN GGG TAT CTA AT-3'. PCR reactions were performed in triplicate $30 \mu \mathrm{l}$ mixtures containing $15 \mu \mathrm{l}$ of $\mathrm{qPCR} \operatorname{mix}, 2 \mu \mathrm{l}$ of $\mathrm{Mg}^{2+}(25 \mathrm{mM}), 0.5 \mu \mathrm{l}$ of each primer $(10 \mu \mathrm{M})$, and $2 \mu \mathrm{l}$ of template DNA. Amplicons were extracted from $2 \%$ agarose gels and purified using the AxyPrep DNA Gel Extraction Kit (Axygen Biosciences) according to the manufacturer's instructions and quantified using QuantiFluor ${ }^{\mathrm{TM}}$-ST (Promega).

The constructed plasmid was linearized, then purified, quantified, and converted to a copy number (copies $\mu^{-1}$ ). A 10-fold gradient dilution of the constructed standard was then made with $90 \mu \mathrm{l}$ of the dilution solution $+10 \mu$ l of the plasmid. A $10^{-2}$ to $10^{-6}$ dilution of the standard was separately prepared by preliminary experiments to prepare a standard curve. The detection of fluorescence quantitative PCR $\left(95^{\circ} \mathrm{C}\right.$ for $3 \mathrm{~min}$, followed by 30 cycles at $94^{\circ} \mathrm{C}$ for $30 \mathrm{~s}, 50^{\circ} \mathrm{C}$ for $30 \mathrm{~s}$ ) reactions were performed in triplicate $30 \mu \mathrm{l}$ mixtures containing $15 \mu$ l of qPCR Mix, $2 \mu \mathrm{l}$ of $\mathrm{Mg}^{2+}$ $(25 \mathrm{mM}), 0.5 \mu \mathrm{l}$ of each primer $(10 \mu \mathrm{M}), 2 \mu \mathrm{l}$ of template DNA, and $0.5 \mu \mathrm{l}$ of dyestuff (Takara TB Green Fast qPCR Mix).

\subsection{Statistical analysis}

All data except the ORP values were subjected to an independent-samples $t$-test or 1-way ANOVA, followed by Duncan's test for multiple comparisons to determine the differences in each parameter between 2 or 3 sets of samples, respectively. The level of significance $(\alpha)$ was 0.05 (where $p<0.05$ was considered significant). The ORP values were subjected to 2-way ANOVA with the main factors of $B$. purificata and measurement time, followed by Duncan's test for multiple comparisons at a significance level of 0.05 .

To evaluate the effects of $B$. purificata bioturbation on the THAA composition and OM degradation in surface sediment, a heat-map was produced by integrating all of the different indexes related to OM degradation. Each of the indexes related to OM degradation was standardized by the min-max. We used 
TBtools (Chen et al. 2020) to construct the heat-map and to standardize the data.

Prior to statistical analysis, raw data were assessed for normality of distribution and homogeneity of variance using Kolmogorov-Smirnov and Levene's tests, respectively (Zar 1999). Data are presented as means $\pm S D(n=3)$. All statistical analyses were performed using SPSS for Windows (Release 22.0).

\section{RESULTS}

\subsection{THAA compositions}

The THAA composition of the experimental diet is shown in Table 1. No $\beta$-Ala or $\gamma$-Aba was detected in the experimental diet. The THAA concentration in the experimental diet was $2009.29 \pm 61.52 \mu \mathrm{mol} \mathrm{g}^{-1}$, approximately 100 times the THAA concentration $\left(19.95 \pm 1.70 \mu \mathrm{mol} \mathrm{g}^{-1}\right)$ of the initial sediment samples.

The THAA composition of the surface sediment is shown in Table 2. The THAA concentration in the BPT was significantly lower than in CON tanks at the end of the experiment $(p<0.05)$, while no significant difference was observed between the final BPT and the initial value $(p>0.05)$. For Asp, Glu, Ser, His,
Met, Ileu, Leu, Lys, and Pro concentrations, there were no significant differences between the final $\mathrm{BPT}$, the final CON, and the initial values ( $>0.05)$. The initial Gly, Tyr, and Phe concentrations were significantly higher than the final BPT and CON $(p<0.05)$, while the initial Thr concentration was significantly lower $(p<0.05)$. The final BPT showed significantly lower Arg and Tyr concentration relative to the final CON and initial value ( $p<0.05)$, and the final CON showed a significantly higher Arg concentration relative to the final BPT and initial value $(p<0.05)$. No significant differences in Gly, Thr, Cys, Val, and Phe were observed between the BPT and CON at the end of the experiment $(p>0.05)$.

Regarding the non-protein AAs, no $\beta$-Ala was detected in the initial sediment samples. The BPT showed significantly higher $\beta$-Ala and $\gamma$-Aba concentrations than $\mathrm{CON}$ at the end of the experiment $(\mathrm{p}<0.05)$. The $\gamma$-Aba concentration in the final CON did not differ from the initial value $(p>0.05)$. Due to the absence of $\beta$-Ala in the initial sediment samples, the initial Asp/ $\beta$-Ala ratio could not be calculated, and no significant differences in the Asp/ $\beta$-Ala and $\mathrm{Glu} / \gamma$-Aba ratios between groups were observed at the end of the experiment $(p>0.05)$.
Table 2. Total hydrolysable amino acid (THAA) composition of the surface sediment. Data are presented as mean $\pm \mathrm{SD}(\mathrm{n}=3)$. Different letters within the same row indicate significant differences $(\mathrm{p}<0.05)$ between the final Bellamya purificata treatment (BPT), the final control (CON), and the corresponding initial values. See Table 1 for abbreviations

\begin{tabular}{|c|c|c|c|}
\hline \multirow{2}{*}{ Amino acid } & \multirow{2}{*}{ Initial } & \multicolumn{2}{|c|}{ - Final - } \\
\hline & & BPT & $\mathrm{CON}$ \\
\hline THAA $\left(\mu \mathrm{mol} \mathrm{g}{ }^{-1}\right)$ & $19.95 \pm 1.70^{\mathrm{a}}$ & $22.38 \pm 0.53^{\mathrm{a}}$ & $37.86 \pm 6.27^{b}$ \\
\hline Asp (mol\%) & $3.99 \pm 1.48$ & $2.58 \pm 1.16$ & $2.84 \pm 1.47$ \\
\hline Glu (mol\%) & $3.61 \pm 1.04$ & $1.54 \pm 1.40$ & $2.59 \pm 1.68$ \\
\hline Ser (mol\%) & $8.19 \pm 0.69$ & $9.56 \pm 0.33$ & $7.95 \pm 1.19$ \\
\hline His $(\mathrm{mol} \%)$ & $1.31 \pm 0.21$ & $1.35 \pm 0.05$ & $1.19 \pm 0.13$ \\
\hline Gly (mol\%) & $17.92 \pm 0.43^{\mathrm{b}}$ & $15.69 \pm 0.16^{\mathrm{a}}$ & $16.29 \pm 0.70^{\mathrm{a}}$ \\
\hline Thr (mol\%) & $7.520 .83^{\mathrm{a}}$ & $11.54 \pm 1.83^{\mathrm{b}}$ & $9.92 \pm 0.37^{b}$ \\
\hline $\operatorname{Arg}(\mathrm{mol} \%)$ & $4.58 \pm 0.28^{b}$ & $3.68 \pm 0.04^{\mathrm{a}}$ & $4.91 \pm 0.04^{\mathrm{c}}$ \\
\hline Ala (mol\%) & $13.73 \pm 0.65^{\mathrm{a}}$ & $14.66 \pm 0.48^{\mathrm{a}}$ & $16.24 \pm 0.32^{\mathrm{b}}$ \\
\hline Tyr (mol\%) & $1.43 \pm 0.01^{\mathrm{c}}$ & $1.09 \pm 0.05^{\mathrm{a}}$ & $1.27 \pm 0.04^{\mathrm{b}}$ \\
\hline Cys (mol\%) & $0.99 \pm 0.43^{b}$ & $0.58 \pm 0.02^{\mathrm{ab}}$ & $0.27 \pm 0.35^{\mathrm{a}}$ \\
\hline Val (mol\%) & $7.23 \pm 0.13^{b}$ & $6.75 \pm 0.45^{\mathrm{ab}}$ & $6.60 \pm 0.17^{a}$ \\
\hline Met (mol\%) & $1.88 \pm 0.18$ & $1.43 \pm 0.69$ & $2.03 \pm 0.26$ \\
\hline Phe (mol\%) & $3.53 \pm 0.50^{\mathrm{b}}$ & $2.65 \pm 0.12^{\mathrm{a}}$ & $2.76 \pm 0.08^{\mathrm{a}}$ \\
\hline Ileu (mol\%) & $4.93 \pm 0.53$ & $4.91 \pm 0.46$ & $5.64 \pm 0.12$ \\
\hline Leu (mol\%) & $8.59 \pm 0.44$ & $8.29 \pm 0.59$ & $8.02 \pm 1.68$ \\
\hline Lys (mol\%) & $5.69 \pm 0.30$ & $5.75 \pm 0.30$ & $5.58 \pm 0.40$ \\
\hline Pro (mol\%) & $4.26 \pm 0.74$ & $4.92 \pm 0.32$ & $4.95 \pm 0.76$ \\
\hline$\beta$-Ala (mol\%) & ND & $0.77 \pm 0.06^{\mathrm{b}}$ & $0.34 \pm 0.15^{\mathrm{a}}$ \\
\hline$\gamma$-Aba $(\mathrm{mol} \%)$ & $0.63 \pm 0.17^{\mathrm{a}}$ & $2.25 \pm 0.07^{\mathrm{b}}$ & $0.56 \pm 0.04^{\mathrm{a}}$ \\
\hline Asp/ $\beta$-Ala ratio & ND & $3.42 \pm 1.83$ & $8.88 \pm 3.53$ \\
\hline $\mathrm{Glu} / \gamma$-Aba ratio & $6.35 \pm 3.54$ & $0.70 \pm 0.65$ & $4.68 \pm 3.22$ \\
\hline
\end{tabular}

\subsection{Degradation indicators}

The indicators of OM degradation status in the sediment are shown in Table 3. The BPT showed a significantly lower DI value than the CON at the end of the experiment $(p<0.05)$. The initial DI value was significantly higher than the final BPT $(p<0.05)$, while no significant differences in the DI between the initial samples and the final CON were observed ( $p>0.05)$. Similar to the DI values, the RI value in the BPT was also significantly lower than the CON at the end of the experiment $(p<0.05)$. The initial RI value was significantly higher than the final BPT and the final CON $(p<0.05)$. The THAA-C $\%$ and THAA-N $\%$ values in the final CON were significantly higher than the initial value $(\mathrm{p}<0.05)$, while no significant differences in the THAA-C $\%$ and THAA-N $\%$ values between the final BPT and the initial values were observed $(p>0.05)$. The 
Table 3. Indicators of the degradation state of organic matter in sediments. Data are presented as mean $\pm \mathrm{SD}(\mathrm{n}=3)$. Different letters within the same column indicate significant differences between the final Bellamya purificata treatment (BPT), the final control $(\mathrm{CON})$, and the corresponding initial values $(\mathrm{p}<0.05)$. DI: degradation index; RI: reactivity index; THAA-C\% (THAA-N\%): carbon(nitrogen)-normalized yield of total hydrolysable amino acids

\begin{tabular}{|c|c|c|c|c|c|}
\hline Group & & DI & RI & THAA-C\% & THAA-N\% \\
\hline Initial & & $0.28 \pm 0.27^{b}$ & $8.12 \pm 1.42^{c}$ & $5.28 \pm 0.31^{\mathrm{a}}$ & $45.45 \pm 3.71^{\mathrm{a}}$ \\
\hline Final & $\begin{array}{l}\text { BPT } \\
\text { CON }\end{array}$ & $\begin{aligned}-0.47 & \pm 0.43^{\mathrm{a}} \\
0.19 & \pm 0.24^{\mathrm{b}}\end{aligned}$ & $\begin{array}{l}1.24 \pm 0.01^{\mathrm{a}} \\
4.52 \pm 0.52^{\mathrm{b}}\end{array}$ & $\begin{array}{l}6.24 \pm 0.44^{\mathrm{a}} \\
9.01 \pm 1.25^{\mathrm{b}}\end{array}$ & $\begin{array}{l}54.31 \pm 5.84^{\mathrm{ab}} \\
68.23 \pm 11.98^{\mathrm{b}}\end{array}$ \\
\hline
\end{tabular}

final BPT showed a significantly lower THAA-C $\%$ value than the final CON $(p<0.05)$. However, the THAA-N\% in the final BPT did not differ from that in the final CON ( $p>0.05)$.

\subsection{ORP values}

The sedimentary ORP values in the BPT and CON during the experimental period are shown in Fig. 1. The ORP values in sediment were significantly affected by Bellamya purificata and by time ( $<<0.05)$, but not by their interaction $(p>0.05)$. Overall, the sediment ORP values were significantly higher in the BPT than in the CON ( $\mathrm{p}<0.05)$. A significant temporal decrease was observed in the sediment ORP values over the $12 \mathrm{wk}$ experimental period $(\mathrm{p}<0.05)$.

\subsection{Bacterial 16S rRNA gene abundance}

The melting curve peak of the sample is consistent with the target peak, and the quantitative values are all greater than 500. The quantitative value is accurate and reliable. Bacterial 16S rRNA gene abundance

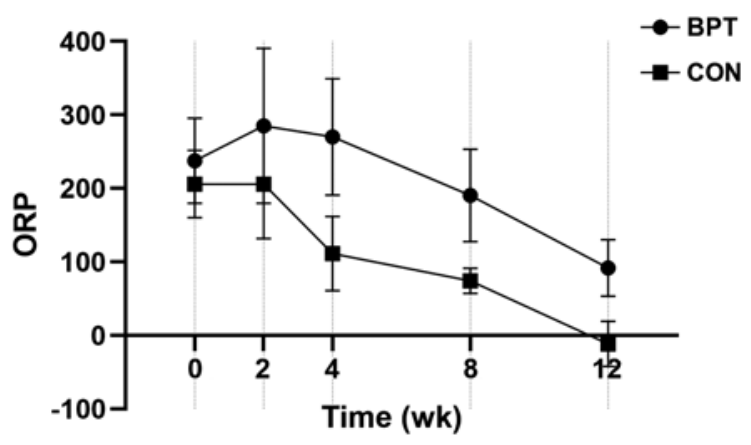

Fig. 1. Dynamic changes of the oxidation-reduction potential (ORP) values during the experimental period. Data are presented as mean $\pm \mathrm{SD}(\mathrm{n}=3)$. BPT: Bellamya purificata treatment; $\mathrm{CON}$ : control at the end of the experiment is shown in Table 4. At the end of the experiment, the copies of the bacterial $16 \mathrm{~S}$ rRNA genes were significantly higher in the BPT than in the CON $(p<0.05)$.

\subsection{TOC and TN concentrations}

The TOC and TN concentrations in the surface sediment are shown in Table 4. At the end of the experiment, the BPT showed significantly lower TOC and TN concentrations relative to the CON ( $\mathrm{p}<$ 0.05), while no significant differences in the TOC and TN concentrations between the final BPT and the initial values were observed ( $p>0.05)$. The TN concentration of the CON at the end of the experiment was significantly higher than the initial value $(\mathrm{p}<0.05)$.

\subsection{Heat-map}

Heat-map visualization of the different indexes related to OM degradation in sediments is shown in Fig. 2. All indexes were up-regulated in the final $\mathrm{CON}$ relative to the final BPT and the initial values, except for the DI and RI. The DI and RI were not consistent with the other indexes; DI and RI values were relatively higher in the initial sediment samples. In terms of the difference between the BPT and the $\mathrm{CON}$, the CON had a higher value for each index, indicating less degraded OM compared to the BPT. By clustering rows in the heat-map, all samples in the experiment were initially divided into 2 categories, where Final CON_1, Final CON_2, and Final CON_3 belonged to one category, and Final BPT_1,

Table 4. Total organic carbon (TOC), total nitrogen (TN), and bacterial 16S rRNA gene abundance in the surface sediment. Data are presented as mean \pm SD $(n=3)$. Different letters within the same column indicate significant differences between the final Bellamya purificata treatment $(\mathrm{BPT})$, the final control (CON), and the corresponding initial values $(\mathrm{p}<0.05)$

\begin{tabular}{|c|c|c|c|c|}
\hline Group & & $\begin{array}{c}\text { TOC } \\
(\%)\end{array}$ & $\begin{array}{l}\mathrm{TN} \\
(\%)\end{array}$ & $\begin{array}{l}\text { 16S rRNA gene } \\
\text { abundance } \\
\left(10^{6} \text { copies g }{ }^{-1}\right)\end{array}$ \\
\hline Initial & & $1.96 \pm 0.08^{\mathrm{ab}}$ & $0.08 \pm 0.00^{a}$ & - \\
\hline Final & $\begin{array}{l}\mathrm{BPT} \\
\mathrm{CON}\end{array}$ & $\begin{array}{l}1.83 \pm 0.10^{\mathrm{a}} \\
2.16 \pm 0.13^{\mathrm{b}}\end{array}$ & $\begin{array}{l}0.07 \pm 0.01^{\mathrm{a}} \\
0.10 \pm 0.02^{\mathrm{b}}\end{array}$ & $\begin{array}{l}27.81 \pm 1.11^{\mathrm{b}} \\
21.03 \pm 2.90^{\mathrm{a}}\end{array}$ \\
\hline
\end{tabular}


Final BPT_2, Final BPT_3, Initial_1, Initial_2, and Initial_3 belonged to the other category. Further clustering showed that Final BPT_1, Final BPT_2, Final BPT_3, Initial_1, Initial_2, and Initial_3 were divided into 2 categories, where Final BPT_1, Final BPT_2, and Final BPT_3 belonged to one category, and Initial_1, Initial_2, and Initial_3 belonged to the other category.

\section{DISCUSSION}

\subsection{OM degradation state}

In terms of the difference between the BPT and the $\mathrm{CON}$ at the end of the experiment, the THAA-C\%, DI, and RI showed a high degree of consistency. For each indicator, the corresponding value in the BPT was significantly lower than that in the CON, which indicated more extensively degraded OM in the surface sediment of the BPT compared to the CON (Jennerjahn \& Ittekkot 1997, Dauwe \& Middelburg 1998, Dauwe et al. 1999, Chen et al. 2018, Zhou et al. 2018). Although the THAA-N\% in the BPT did not significantly differ from the CON at the end of the experiment, the trend among the rows in Table 3 suggests that Bellamya purificata bioturbation promotes the degradation of sedimentary OM in the BPT (Chen et al. 2018, Zhou et al. 2018). When considering the initial values, the THAA-C\%, THAA-N\%, DI, and RI were not highly consistent, differing in the relative size relationship between the initial values and the corresponding final values in the BPT and the CON. Due to the high THAA concentration in the experimental diets, the continuous input of feed resulted in significantly higher THAA-C\% and THAA-N\% values in the CON at the end of the experiment than the initial values, which implied the accumulation of fresh OM in the sediment of the CON. However, the initial DI and RI values were significantly higher than the final values in the CON. The degradation states of the initial samples indicated by the DI and RI were inconsistent with the THAA-C\% and THAA-N\%. Similarly, Chen et al. (2018) also discovered that the DI and RI did not exhibit a consistent trend with the THAA-C $\%$.

As demonstrated in previous studies, different degradation indicators have different sensitivities and applicability at different degradation stages or in different environmental media (Unger et al. 2005, Davis et al. 2009, Chen et al. 2018). For instance, Unger et al. (2005) found that the RI was a more sensitive indicator for degradation of suspended

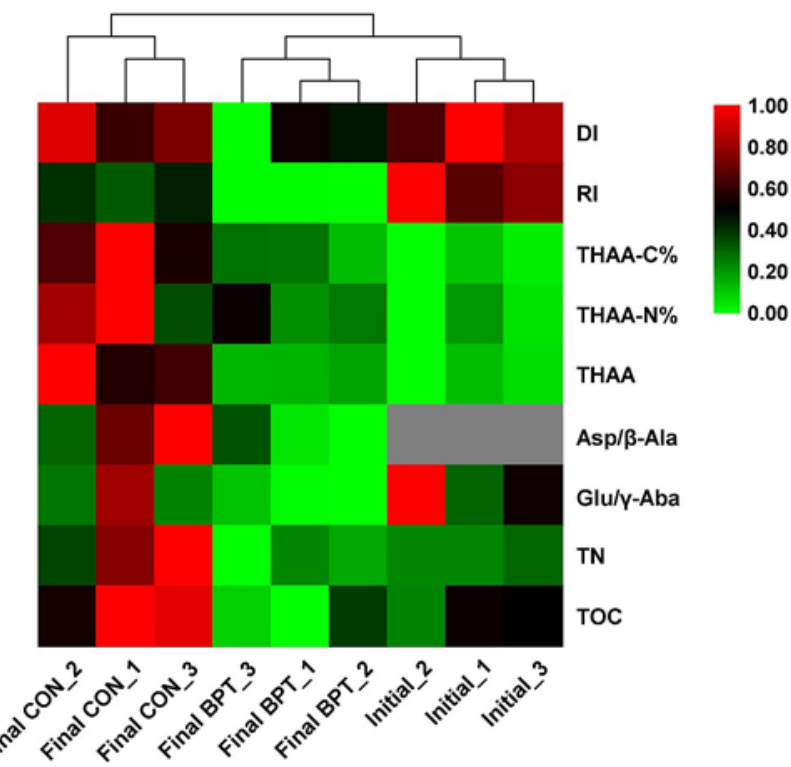

Fig. 2. Heat-map visualization of different indexes related to organic matter degradation in sediments of the final Bellamya purificata treatment (BPT), final control (CON), and initial samples $(\mathrm{n}=3$ replicates per group). For each row, colour represents the relative values of each index in different groups, from the highest (red) to the lowest (green). Note: $\beta$-Ala was not detected in the initial sediment samples, therefore the colour of the Asp/ $\beta$-Ala ratio in the Initial_1, Initial_2, and Initial_3 is grey. DI: degradation index; RI: reactivity index; THAA-C \% (THAA-N\%): carbon- (nitrogen)normalized yield of total hydrolysable amino acids

particulate $\mathrm{OM}$ in the water column, when tracing the degradation intensity from plankton-dominated suspended particulate OM to degraded sediments through combined application of DI and RI. The DI appeared to be effective to indicate degradation alteration of dissolved OM during intermediate stages and useful for the differentiation of degradation stages in sediments, but was not reliable for indicating OM degradation in the early degradation stages (Unger et al. 2005, Davis et al. 2009). The THAA-C $\%$ is considered the most sensitive indicator in early degradation stages of dissolved OM and particulate OM (Cowie \& Hedges 1994, Davis et al. 2009), and the THAA-C\% is also more sensitive for indicating early degradation in sediment compared to DI and RI (Chen et al. 2018). The present study was conducted for $84 \mathrm{~d}$ and mainly documented very early phases of diagenesis (days to months; Davis et al. 2009); therefore, the contradiction might imply that the DI and RI values were not as sensitive as the THAA-C\% in the early stages of degradation in sediments (Chen et al. 2018).

Moreover, when indicating the degradation status of OM, the DI and RI calculated based on the AA 
composition could be affected by the sources of AAs (Ingalls et al. 2003, Carstens \& Schubert 2012, Bianchi et al. 2014, Zhu et al. 2014, Carr et al. 2016, Zhang et al. 2016). Hence, the AA sources might be an important factor influencing the sensitivities and effectiveness of DI and RI when evaluating the OM degradation status in the present study, since the final samples in the BPT and CON were collected after weeks of continuous feed input relative to initial samples. The differences in the AA sources between the initial samples and final samples are a non-negligible reason for the contradiction discussed above. Accordingly, the THAA$\mathrm{C} \%$ might be the most effective in indicating the OM degradation status in sediments. Although the sensitivity of each indicator was different, especially when assessing the degradation status of OM in initial samples, the enhanced OM degradation caused by $B$. purificata bioturbation was confirmed through the high consistency between the DI, RI, and THAA-C\% in indicating the OM degradation status of the final BPT and CON.

\subsection{THAA compositions}

The THAAs comprised a major portion of TOC and TN in sediment, especially freshly produced OM (Zhou et al. 2018). A compositional change occurs in the sedimentary THAAs during the early stage of OM degradation, which can be attributed to an alteration resulting from the degradation and different reactivity of individual AAs (Bourgoin \& Tremblay 2010). The relative contents of individual AAs can also be used to reflect the degradation of OM. In the present study, the THAA concentration in the final CON was significantly higher than the initial value and the final BPT, while no significant difference was observed between the initial value and the final BPT. $B$. purificata could effectively prevent the accumulation of THAAs resulting from the continuous input of feed, which was consistent with the degradation state influenced by bioturbation.

For the compositional changes in THAAs, it is worth noting that no significant differences in the Glu mol\% between initial samples, final BPT, and final CON were observed. In the present study, the Glu $\mathrm{mol} \%$ in the experimental diets was $20.26 \pm$ 0.04 , while the Glu mol\% in the initial sediment samples was only $3.61 \pm 1.04$. With the continuous input of feed, no significant increased Glu content in final BPT or even final CON, compared with the initial samples, might indicate that Glu was easily degraded. In fact, Glu, Tyr, and Phe are the most labile species and are easily degraded (Cowie \& Hedges 1992, Cowie et al. 1992). The significantly lowest Tyr content in the final BPT suggested enhanced degradation of Tyr by $B$. purificata. In addition, the significantly increased contents of non-protein AAs ( $\beta$-Ala and $\gamma$-Aba) in the final BPT are also worth noting, since $\beta$-Ala and $\gamma$-Aba were absent in the feed. Non-protein AAs are thought to originate from diagenesis, accounting for only a negligible fraction of the THAAs in organisms; however, they are relatively abundant in sediment, especially $\beta$-Ala and $\gamma$-Aba (Whelan 1977, Cowie \& Hedges 1994, Davis et al. 2009, Zhou et al. 2018). $\beta$-Ala and $\gamma$-Aba, as the products of Asp and Glu from a microbial decarboxylation reaction, will accumulate during OM degradation, and their concentrations can be used to infer the microbial processing and OM degradation state (Lee \& Cronin 1982, Ittekkot et al. 1984, Dauwe \& Middelburg 1998, Davis et al. 2009, Zhou et al. 2018). For the present study, the significantly highest contents of $\beta$-Ala and $\gamma$-Aba in the BPT suggested that the presence of $B$. purificata promoted the production of non-protein AAs and the degradation of OM in the surface sediment.

Previous studies have used the Asp/ $\beta$-Ala and $\mathrm{Glu} / \gamma$-Aba ratios to further describe microbial processing and OM degradation, whereby lower ratios reflect greater microbial transformation and degradation (Ittekkot et al. 1984, Dauwe \& Middelburg 1998, Wang et al. 2018). For this study, no significant differences were observed in the Asp/ $\beta$-Ala and $\mathrm{Glu} / \gamma$-Aba ratios among the groups, which was inconsistent with the results of the degradation state indicators discussed in Section 4.1. Wang et al. (2018) also reported that the Asp/ $\beta$-Ala and Glu/ $\gamma$-Aba ratios may not be very accurate and effective. In fact, decarboxylation may not be the principal reaction for Asp and Glu; in many cases, Asp and Glu do not produce $\beta$-Ala and $\gamma$-Aba during degradation (Cowie $\&$ Hedges 1994). Therefore, such ratios may not indicate degradation accurately, but they can still be used as a reference for determining the OM degradation state.

\subsection{How bioturbation affects $\mathrm{OM}$}

Environmental factors that can affect the remineralization of $\mathrm{OM}$ in sediment are locally influenced by the macrofauna (Yazdani Foshtomi et al. 2015). Oxygen, as the principal electron acceptor, is a key com- 
ponent affecting the remineralization of OM. Oxic remineralization processes are the most efficient in promoting the net remineralization and reoxidation of bulk OM on short time scales, and even brief $\left(\sim 20 \%\right.$ time) periodic exposure to $\mathrm{O}_{2}$ may approximate some of the same results through alternate paths (Aller 1994). Previous studies have shown that water and solute transportation at the sedimentwater interface are mainly affected by benthic activities (Aller 2001, Grenz et al. 2003, Meysman et al. 2006). The mechanical disturbance caused by the activity of the benthic fauna can increase the contact area between the sediment and the upper water body, transport oxygen into the sediment, and finally, increase the supply of electron acceptors in the sediment (Massin 1982a,b, van de Bund et al. 1994, SanzLázaro \& Marín 2011). The significantly higher ORP value in the BPT than the CON in the present study indicated that $B$. purificata could effectively transport oxygen from the oxygenated overlying water into the surface sediment, which is consistent with the higher ORP values driven by worms (Lumbrinereis latreilli) reported by Casado-Coy et al. (2020). Hence, the more extensive degradation of OM in the BPT could be attributed to the bioturbation of $B$. purificata improving the ORP values.

However, OM degradation in sediment is essentially a microbial process. Previous studies have shown that bioturbation can not only affect the metabolism and activity of bacteria (Rugenski et al. 2012), but can also alter the structure and diversity of bacterial communities in sediment (Mermillod-Blondin et al. 2004, Laverock et al. 2010). Both are closely related to biogeochemical processes in sediment (Lohrer et al. 2004, Bertics \& Ziebis 2009), including $\mathrm{OM}$ degradation. In the present study, BPT showed significantly higher copies of bacterial 16S rRNA genes relative to the CON, which suggests the influence of $B$. purificata on the bacterial population. Macrofaunal bioturbation can convert large organic particles into small organic particles, which can be more easily utilized by microorganisms, thereby improving the microbial OM availability (Levin et al. 1997, Kristensen \& Holmer 2001, Kristensen et al. 2012). The significant differences in the bacterial 16S rRNA gene abundance between the BPT and the CON could be attributed to the more easily utilized $\mathrm{OM}$ that resulted from bioturbation. Furthermore, the ORP values in the present study indicated that the macrofauna could enhance microbial respiration by increasing the supply of high-energy electron acceptors $\left(\mathrm{O}_{2}\right)$, which promote OM degradation (Jørgensen 1989,
Aller \& Aller 1998, Christensen et al. 2000). Accordingly, the enhanced OM degradation by $B$. purificata might be attributable to $B$. purificata enhancing the bacterial population and respiration by increasing the availability of electron acceptors $\left(\mathrm{O}_{2}\right)$ and $\mathrm{OM}$.

The significant differences in TOC and TN contents between the BPT and the CON in the present study were consistent with the OM degradation states discussed above. In fact, B. purificata prefers to inhabit silt and ingest organic debris in its surroundings (Reavell 1980, Cao \& Jiang 1998). Ingestion and digestion by $B$. purificata were also important contributors to the reduction of TOC and TN in the sediment and to the changes in OM and AA composition. Moreover, the faeces from macrobenthos also have a non-negligible impact on $\mathrm{OM}$ concentrations in the sediment. Brown (1986) found that the faecal pellets derived from the mud snail Hydrobia ulvae (Pennant) and bivalve molluscs contained higher organic carbon content than the sediment. Similarly, the shrimp Fenneropenaeus chinensis and sandprawn Callianassa kraussi could also increase the OM concentrations in sediment through faecal production (Pillay et al. 2011, Ren 2012). Therefore, considering the consumption, production of faeces, and bioturbation, this study mainly aimed to investigate the overall impact of $B$. purificata on the OM in sediments. Through the mutual consistence and verification between the degradation state indicators, THAA composition, and OM contents (TOC and TN), it is confirmed that $B$. purificata can accelerate OM degradation, thereby inhibiting the accumulation of $\mathrm{OM}$ in the surface sediment.

In conclusion, during the $84 \mathrm{~d}$ culturing experiment, the presence of $B$. purificata effectively increased the ORP values of the sediments, providing sufficient high-energy electron acceptors $\left(\mathrm{O}_{2}\right)$, improved the bacterial population and respiration, subsequently promoted OM degradation, and finally inhibited the accumulation of OM in the sediment. Hence, B. purificata played an important role in OM removal and improved resource utilization in sediment. The application of $B$. purificata in integrated multi-trophic aquaculture systems may therefore prevent eutrophication in aquaculture waters and reduce the risk of OM accumulation in sediment. In addition, the degradation indicators based on the AAs can help to further study the ecological systems of aquaculture ponds; however, considering the differences in sensitivity and applicability among the different indicators, comprehensive use and analysis are necessary to avoid errors. 
Acknowledgements. This work was financially supported by the National Natural Science Foundation of China (grant no. 31802302), the Modern Agriculture Industrial Technology System Special Project - the National Technology System for Conventional Freshwater Fish Industries (grant no. CARS-45), the Natural Science Foundation of Jiangsu Province, China (grant no. BK20180173), and the Central Public-interest Scientific Institution Basal Research Fund, Freshwater Fisheries Research Center, CAFS (no. 2018JBFR05).

\section{LITERATURE CITED}

Aller RC (1988) Benthic fauna and biogeochemical processes in marine sediments: the role of burrow structures. In: Blackburn TH, Sørensen J (eds) Nitrogen cycling in coastal marine environments. John Wiley \& Sons, Chichester, p 301-338

Aller RC (1994) Bioturbation and remineralization of sedimentary organic matter: effects of redox oscillation. Chem Geol 114:331-345

Aller RC (2001) Transport and reactions in the bioirrigated zone. In: Boudreau BP, Jørgensen BB (eds) The benthic boundary layer: transport processes and biogeochemistry. Oxford University Press, New York, NY, p 269-301

Aller RC, Aller JY (1998) The effect of biogenic irrigation intensity and solute exchange on diagenetic reaction rates in marine sediments. J Mar Res 56:905-936

Amon RMW, Benner R (2003) Combined neutral sugars as indicators of the diagenetic state of dissolved organic matter in the Arctic Ocean. Deep Sea Res I 50:151-169

* Amon RMW, Fitznar HP, Benner R (2001) Linkages among the bioreactivity, chemical composition, and diagenetic state of marine dissolved organic matter. Limnol Oceanogr 46:287-297

Bertics VJ, Ziebis W (2009) Biodiversity of benthic microbial communities in bioturbated coastal sediments is controlled by geochemical microniches. ISME J 3: 1269-1285

* Bianchi TS, Grace BL, Carman KR, Maulana I (2014) Amino acid cycling in the Mississippi River Plume and effects from the passage of Hurricanes Isadore and Lili. J Mar Syst 136:10-21

Bourgoin LH, Tremblay L (2010) Bacterial reworking of terrigenous and marine organic matter in estuarine water columns and sediments. Geochim Cosmochim Acta 74: 5593-5609

Brönmark C, Vermaat JE (1998) Complex fish-snail-epiphyton interactions and their effects on submerged freshwater macrophytes. In: Jeppesen E, Søndergaard M, Søndergaard M, Christoffersen K (eds) The structuring role of submerged macrophytes in lakes. Ecological Studies (Analysis and Synthesis), Vol 131. Springer, New York, NY, p 47-68

Brown SL (1986) Feces of intertidal benthic invertebrates: influence of particle selection in feeding ace element concentration. Mar Ecol Prog Ser 28:219-231

Cao ZG, Jiang XP (1998) The influence of environmental factors on Bellamya purificata. J Shanghai Fish Univ 7 : 200-205 (in Chinese with English abstract)

* Carlsson MS, Engström P, Lindahl O, Ljungqvist L, Petersen JK, Svanberg L, Holmer M (2012) Effects of mussel farms on the benthic nitrogen cycle on the Swedish west coast. Aquacult Environ Interact 2:177-191

Carr SA, Mills CT, Mandernack KW (2016) The use of amino acid indices for assessing organic matter quality and microbial abundance in deep-sea Antarctic sediments of IODP expedition 318. Mar Chem 186:72-82

* Carstens D, Schubert CJ (2012) Amino acid and amino sugar transformation during sedimentation in lacustrine systems. Org Geochem 50:26-35

Casado-Coy N, Sánchez-Jerez P, Holmer M, Sanz-Lázaro C (2020) Bioturbation may not always enhance the metabolic capacity of organic polluted sediments. Mar Environ Res 155:104882

* Chen C, Chen H, Zhang Y, Thomas HR, Frank MH, He Y, Xia R (2020) TBtools: an integrative toolkit developed for interactive analyses of big biological data. Molecular Plant 13:1194-1202

Chen J, Song GT, Wang X, She L, Wu S, Wu ML, Ding FQ (2012) The efficiency of water purification by different densities of Bellamya aeruginosa and Bellamya purificata. J Anhui Agric 40:11708-11709 (in Chinese with English abstract)

* Chen Y, Yang GP, Liu L, Zhang PY, Leng WS (2016) Sources, behaviors and degradation of dissolved organic matter in the East China Sea. J Mar Syst 155:84-97

* Chen Y, Yang GP, Ji CX, Zhang HH, Zhang PY (2018) Sources and degradation of sedimentary organic matter in the mud belt of the East China Sea: implications from the enantiomers of amino acids. Org Geochem 116:51-61

* Christensen B, Vedel A, Kristensen E (2000) Carbon and nitrogen fluxes in sediment inhabited by suspensionfeeding (Nereis diversicolor) and non-suspension-feeding (N. virens) polychaetes. Mar Ecol Prog Ser 192:203-217

* Cowie GL, Hedges JI (1992) Sources and reactivities of amino acids in a coastal marine environment. Limnol Oceanogr 37:703-724

* Cowie GL, Hedges JI (1994) Biochemical indicators of diagenetic alteration in natural organic matter mixtures. Nature 369:304-307

Cowie GL, Hedges JI, Calvert SE (1992) Sources and relative reactivities of amino acids, neutral sugars, and lignin in an intermittently anoxic marine environment. Geochim Cosmochim Acta 56:1963-1978

* Dauwe B, Middelburg JJ (1998) Amino acids and hexosamines as indicators of organic matter degradation state in North Sea sediments. Limnol Oceanogr 43: 782-798

*Dauwe B, Middelburg JJ, Herman PM, Heip CH (1999) Linking diagenetic alteration of amino acids and bulk organic matter reactivity. Limnol Oceanogr 44: 1809-1814

*Davis J, Kaiser K, Benner R (2009) Amino acid and amino sugar yields and compositions as indicators of dissolved organic matter diagenesis. Org Geochem 40:343-352

*Diaz RJ (2001) Overview of hypoxia around the world. J Environ Qual 30:275-281

Dong JS, Chen HJ, Wang XH (2009) Effects of snails feeding rates on size, yield and survival of Chinese mitten crab Eriocheir sinensis. Fish Sci 28:691-694 (in Chinese with English abstract)

Duan XJ (2013) Feeding habits and selectivity of Bellamya purificata in ecological ditch. MSc dissertation, Huazhong Agriculture University, Wuhan (in Chinese with English abstract)

Fernandes L, Garg A, Borole D (2014) Amino acid biogeochemistry and bacterial contribution to sediment organic matter along the western margin of the Bay of Bengal. Deep Sea Res I 83:81-92 
Godel H, Seitz P, Verhoef M (1992) Automated amino acid analysis using combined OPA and FMOC-Cl precolumn derivatization. LC-GC Int 5:44-49

Gray JS, Wu RSS, Or YY (2002) Effects of hypoxia and organic enrichment on the coastal marine environment. Mar Ecol Prog Ser 238:249-279

*Genz C, Denis L, Boucher G, Chauvaudd L, Clavierd J, Ficheze R, Pringault O (2003) Spatial variability in sediment oxygen consumption under winter conditions in a lagoonal system in New Caledonia (South Pacific). J Exp Mar Biol Ecol 285-286:33-47

Gu QH, Zhou CJ, Cheng QQ, Li XJ and others (2015) The perplexing population genetic structure of Bellamya purificata (Gastropoda: Viviparidae): low genetic differentiation despite low dispersal ability. J Molluscan Stud 81:466-475

Hargrave BT, Holmer M, Newcombe CP (2008) Towards a classification of organic enrichment in marine sediments based on biogeochemical indicators. Mar Pollut Bull 56: 810-824

Hou YR, Sun YJ, Gao QF, Dong SL, Wen B, Pan Z, Liu C (2018) Bioturbation by sea cucumbers Apostichopus japonicus affects sediment phosphorus forms and sorption characteristics. Aquacult Environ Interact 10:201-211

Ingalls AE, Lee C, Wakeham SG, Hedges JI (2003) The role of biominerals in the sinking flux and preservation of amino acids in the Southern Ocean along $170^{\circ} \mathrm{W}$. Deep Sea Res I 50:713-738

Ittekkot V, Deuser WG, Degens ET (1984) Seasonality in the fluxes of sugars, amino acids, and amino sugars to the deep ocean: Sargasso Sea. Deep Sea Res A Oceanogr Res Pap 31:1057-1069

Jennerjahn TC, Ittekkot V (1997) Organic matter in sediments in the mangrove areas and adjacent continental margins of Brazil: I. Amino acids and hexosamines. Oceanol Acta 20:359-370

Ji XL, Lin XT, Xu ZN, Lin YT (2000) Mechanism of mariculture self-pollution and its effects on environment. Haiyang Huanjiang Kexue 19:66-71 (in Chinese with English abstract)

Jørgensen BB (1989) Biogeochemistry of chemoautotrophic bacteria. In: Schlegel HG, Bowen B (eds) Autotrophic bacteria. Science Tech Publ, Madison, WI, p 117-146

Kaiser K, Benner R (2008) Major bacterial contribution to the ocean reservoir of detrital organic carbon and nitrogen. Limnol Oceanogr 53:99-112

Kaiser K, Benner R (2009) Biochemical composition and size distribution of organic matter at the Pacific and Atlantic time-series stations. Mar Chem 113:63-77

Keil RG, Tsamakis E, Hedges JI (2000) Early diagenesis of particulate amino acids in marine sediments. In: Goodfriend GA, Collins MJ, Fogel ML, Macko SA, Wehmiller JF (eds) Perspectives in amino acid and protein chemistry. Oxford University Press, New York, NY, p 69-82

K Kristensen E, Holmer M (2001) Decomposition of plant materials in marine sediment exposed to different electron acceptors $\left(\mathrm{O}_{2}, \mathrm{NO}_{3}{ }^{-}\right.$, and $\left.\mathrm{SO}_{4}{ }^{2-}\right)$, with emphasis on substrate origin, degradation kinetics, and the role of bioturbation. Geochim Cosmochim Acta 65:419-433

Kristensen E, Penha-Lopes G, Delefosse M, Valdemarsen T, Quintana CO, Banta GT (2012) What is bioturbation? The need for a precise definition for fauna in aquatic sciences. Mar Ecol Prog Ser 446:285-302

Kaverock B, Smith CJ, Tait K, Osborn AM, Widdicombe S, Gilbert JA (2010) Bioturbating shrimp alter the structure and diversity of bacterial communities in coastal marine sediments. ISME J 4:1531-1544

Lee C, Cronin C (1982) The vertical flux of particulate organic nitrogen in the sea: decomposition of amino acids in the Peru upwelling area and the equatorial Atlantic. J Mar Res 40:227-251

* Levin L, Blair N, DeMaster D, Plaia G, Fornes W, Martin C, Thomas C (1997) Rapid subduction of organic matter by maldanid polychaetes on the North Carolina slope. J Mar Res 55:595-611

Liang L, Wang YY, Yao JJ (2013) Analysis and evaluation on nutritional composition of three freshwater snails in Jinjiang River. Guizhou Agric Sci 41:131-133 (in Chinese with English abstract)

Liu XG (2011) Study on the pond aquaculture pollution and ecological engineering regulation techniques. PhD dissertation, Nanjing Agricultural University (in Chinese with English abstract)

Liu YY (1979) Freshwater mollusks. Economic fauna of China. Science Press, Beijing (in Chinese)

*Lohrer AM, Thrush SF, Gibbs MM (2004) Bioturbators enhance ecosystem function through complex biogeochemical interactions. Nature 431:1092-1095

Massin C (1982a) Food and feeding mechanisms: Holothuroidea. In: Jangoux M, Lawrence J (eds) Echinoderm nutrition. Balkema, Rotterdam, p 43-55

Massin C (1982b) Effects of feeding on the environment: Holothuroidea. In: Jangoux M, Lawrence J (eds) Echinoderm nutrition. Balkema, Rotterdam, p 493-497

* Mermillod-Blondin F, Rosenberg R, François-Carcaillet F, Norling K, Mauclaire L (2004) Influence of bioturbation by three benthic infaunal species on microbial communities and biogeochemical processes in marine sediment. Aquat Microb Ecol 36:271-284

*Meysman FJR, Middelburg JJ, Heip CH (2006) Bioturbation: a fresh look at Darwin's last idea. Trends Ecol Evol 21:688-695

Ministry of Agriculture and Rural Affairs PRC (2018) China fishery statistical yearbook. China Agriculture Publisher, Beijing

* Murray JMH, Meadows A, Meadows PS (2002) Biogeomorphological implications of microscale interactions between sediment geotechnics and marine benthos: a review. Geomorphology 47:15-30

Nie XB, Wu SJ, Wu FT, Sun SQ, Jiang CB, Tan WC, Wan JL (2011) Effects of the bioturbation activity of Tubifex tubifex on nitrogen release from sediments. Acta Sci Circumst 31:107-113 (in Chinese with English abstract)

* Papaspyrou S, Gregersen T, Kristensen E, Christensen B, Cox RP (2006) Microbial reaction rates and bacterial communities in sediment surrounding burrows of two nereidid polychaetes (Nereis diversicolor and N. virens). Mar Biol 148:541-550

*Pelegrí PS, Blackburn TH (1994) Bioturbation effects of the amphipod Corophium volutator, on microbial nitrogen transformations in marine sediments. Mar Biol 121: 253-258

*Pillay D, Branch GM, Dawson J, Henry D (2011) Contrasting effects of ecosystem engineering by the cordgrass Spartina maritima and the sandprawn Callianassa kraussi in a marine-dominated lagoon. Estuar Coast Shelf Sci 91:169-176

Reavell P (1980) A study of the diets of some British freshwater gastropods. J Conchol 30:253-271

Ren YC (2012) Studies on the bio-deposition and related ecological effects in different polyculture mode of sea 
cucumber Apostichopus japonicus (Selenka) culture pond. PhD dissertation, Ocean University of China, Qingdao (in Chinese with English abstract)

Rugenski AT, Murria C, Whiles MR (2012) Tadpoles enhance microbial activity and leaf decomposition in a neotropical headwater stream. Freshw Biol 57:1904-1913

Sanz-Lázaro C, Marín A (2008) Assessment of finfish aquaculture impact on the benthic communities in the Mediterranean Sea. Dyn Biochem Process Biotechnol Mol Biol 2 (Spec Issue 1):21-32

Sanz-Lázaro C, Marín A (2011) Diversity patterns of benthic macrofauna caused by marine fish farming. Diversity (Basel) 3:176-199

Shao JM, Peng G, Li JJ, Han F (2011) Development status and issues of recirculating pond aquaculture in Jiangsu Province. J Aquacult 08:33-35

Stockdale A, Davison W, Hao Z (2009) Micro-scale biogeochemical heterogeneity in sediments: a review of available technology and observed evidence. Earth Sci Rev 92:81-97

Tian GT, Gong JX, Zhang JL, Du XH, Liu F, Zhang ML, Duan DX (2012) Effects of different culturing modes on pond environment and output of Trionyx sinensis. J Hydroecol 33:96-100 (in Chinese with English abstract)

Unger D, Gaye-Haake B, Neumann K, Gebhardt AC, Ittekkot V (2005) Biogeochemistry of suspended and sedimentary material in the $\mathrm{Ob}$ and Yenisei rivers and Kara Sea: amino acids and amino sugars. Cont Shelf Res 25:437-460

van de Bund WJ, Goedkoop W, Johnson RK (1994) Effects of deposit-feeder activity on bacterial production and abundance in profundal lake sediment. J N Am Benthol Soc 13:532-539

Wang K, Chen J, Jin H, Li H, Zhang W (2018) Organic matter degradation in surface sediments of the Changjiang estuary: evidence from amino acids. Sci Total Environ 637-638:1004-1013

Wang YY, Song JX, Jiang WW, Cheng DD and others (2015) Effect of bioturbation of chironomid larvae and Limnodrilus hoffmeisteri on the release of nitrogen, oxygen and

Editorial responsibility: Tim Dempster,

Melbourne, Victoria, Australia phosphate in the sediments from a river. Acta Sci Circumst 35:2504-2511 (in Chinese with English abstract)

*Whelan JK (1977) Amino acids in a surface sediment core of the Atlantic abyssal plain. Geochim Cosmochim Acta 41: 803-810

Yan YJ, Jin W, Wen HB, Ma XY and others (2018) Estimation of genetic parameters for growth traits of Bellamya purificata in 60 days. Freshw Fish 48:108-111 (in Chinese with English abstract)

*Yazdani Foshtomi M, Braeckman U, Derycke S, Sapp M, Van Gansbeke D, Sabbe K, Vanaverbeke J (2015) The link between microbial diversity and nitrogen cycling in marine sediments is modulated by macrofaunal bioturbation. PLOS ONE 10:e0130116

Zar JH (1999) Biostatistical analysis, $4^{\text {th }}$ edn. Prentice-Hall, Englewood Cliffs, NJ

Zhang L, Gu X, Wang Z, Shen Q, Fan C, Zhong J, Yin H (2010) The influence of tubificid worms bioturbation on the exchange of phosphorus across sediment-water interface in lakes. Hupo Kexue 22:666-674 (in Chinese with English abstract)

Z Zhang PY, Yang GP, Chen Y, Leng WS, Ji CX (2016) Temporal and spatial variations of particulate and dissolved amino acids in the East China Sea. Mar Chem 186: 133-144

Zhao F (2014) Studies on the community structure and some ecological function of macrozoobenthos in pond. PhD dissertation, Huazhong Agricultural University, Wuhan (in Chinese with English abstract)

Zhou B, Yuan HM, Li XG, Li N, Duan LQ, Ren CJ (2018) Amino acids in marine particulate matters and sediments and their role as indicators for organic matter degradation. Yingyong Shengtai Xuebao 29:3147-3158 (in Chinese with English abstract)

* Zhu ZY, Wu Y, Zhang J, Dittmar T, Li Y, Shao L, Ji Q (2014) Can primary production contribute non-labile organic matter in the sea: amino acid enantiomers along the coast south of the Changjiang Estuary in May. J Mar Syst 129:343-349

Submitted: February 15, 2020; Accepted: October 2, 2020 Proofs received from author(s): December 17, 2020 